Check for updates

Cite this: RSC Adv., 2019, 9, 5628

Received 30th November 2018 Accepted 31st January 2019

DOI: $10.1039 / c 8 \mathrm{ra09853k}$

rsc.li/rsc-advances

\title{
A green approach of preparation of fine active alumina with high specific surface area from sodium aluminate solution
}

\author{
Guoyu Wu, (D) Guihua Liu, (D) * Xiaobin Li, Zhihong Peng, Qiusheng Zhou (D) \\ and Tiangui Qi
}

Fine active alumina (FAA) with a high specific surface area (SSA) is used in catalysis, adsorbents and other applications. This study presents a novel method of preparing high surface area FAA via a phase evolution from gibbsite through ammonium aluminum carbonate hydroxide (AACH) to FAA. Thermodynamic calculations showed that increasing the $\mathrm{pH}$ and $\left(\mathrm{NH}_{4}\right)_{2} \mathrm{CO}_{3}$ concentration both promoted the transformation of gibbsite to $\mathrm{AACH}$. Fine gibbsite precipitated from a sodium aluminate solution could thus be efficiently changed to $A A C H$ and subsequently to FAA. Minimal particle aggregation was achieved from gibbsite to AACH to FAA owing to the filling of capillaries by $\mathrm{NH}_{3}$ and $\mathrm{CO}_{2}$, the formation of boehmite and interfacial hydrophobicity. Furthermore, capillary pressures of 1.2546.56 MPa during the $\mathrm{AACH}$ roasting process prevented the collapse of mesopores. The high capillary pressure, numerous open mesopores, and inhibition of aggregation produced FAA with an extremely high SSA. The SSA of FAA was as high as $1088.72 \mathrm{~m}^{2} \mathrm{~g}^{-1}$ following the roasting of $\mathrm{AACH}$ at $300{ }^{\circ} \mathrm{C}$ for $180 \mathrm{~min}$. This FAA was demonstrated to remove phosphate from wastewater with an adsorption capacity of $300.28 \mathrm{mg} \mathrm{g}^{-1}$.

\section{Introduction}

$\gamma-\mathrm{Al}_{2} \mathrm{O}_{3}$ is widely used in catalysts, catalyst supports, wastewater purification, gas separation, automobile exhaust emission reduction systems and flue gas cleaning. ${ }^{1}$ As many of those applications depend on a large specific surface area (SSA), increasing the SSA of active alumina is an important research challenge.

Because the SSA of fine alumina is often less than $250 \mathrm{~m}^{2}$ $\mathrm{g}^{-1}$, the SSA is typically increased by preparing nano-alumina as well as by regulating the pore structure of the material. Various methods have been developed for the preparation of nanoalumina, including chemical vapor deposition, ${ }^{2}$ mechanical grinding, ${ }^{3}$ chemical pyrolysis, ${ }^{4}$ wet sol-gel, ${ }^{5,6}$ microemulsion, ${ }^{7}$ precipitation $^{8-10}$ and hydrothermal synthesis. ${ }^{11}$ Among these, the wet method has been extensively investigated owing to its low cost, simplicity and ready industrial application. However, the unavoidable aggregation of nano-particles during precipitation from solution as well as during drying or roasting can greatly increase the particle size. Hence, various additional processes to inhibit aggregation have also been reported. In those approaches, an $\mathrm{Al}(\mathrm{OH})_{3}$ or $\mathrm{AlOOH}$ precursor is first carefully prepared, such as by diluting a more concentrated solution, ${ }^{\mathbf{1 2}}$ modifying the solvent properties of a solution via the

School of Metallurgy and Environment, Central South University, Changsha 410083, Hunan, China.E-mail: liugh303@csu.edu.cn addition of organic solvents, ${ }^{\mathbf{1 3 , 1 4}}$ adding a surfactant or chelator, ${ }^{\mathbf{1 5}}$ modifying the particle surfaces ${ }^{\mathbf{1 6}}$ or coating the particle surfaces. ${ }^{17}$ Various approaches, including azeotropic distillation, ${ }^{18}$ freeze-drying, ${ }^{19}$ supercritical drying ${ }^{20}$ and surface modification, ${ }^{21}$ are subsequently applied during drying or roasting (calcining) of the precursor. Additionally, the pore structure (pore size, pore volume) can be tuned so as to increase the SSA, such as surfactants, ${ }^{5,6}$ templates, ${ }^{22-25}$ coupling templates $^{26}$ or pore-expanding agents. ${ }^{27-29}$ Those techniques increase the SSA of nano-alumina to the range of 200 to $700 \mathrm{~m}^{2}$ $\mathrm{g}^{-1}$. Even so, such methods are expensive and tend to generate large amounts of high salinity waste water. Meanwhile, the fine active alumina (FAA) can be prepared in an economically friendly, economical manner using a sodium aluminate solution, which leads to less aggregation compared to nanoparticles, ${ }^{30}$ although the low SSA of this material $\left(<300 \mathrm{~m}^{2} \mathrm{~g}^{-1}\right)$ limits its applications. Therefore, a green, economical methods of synthesizing FAA have a high SSA $\left(>500 \mathrm{~m}^{2} \mathrm{~g}^{-1}\right)$ is required.

Ammonium aluminum carbonate hydroxide (AACH) is often used as a precursor for FAA production. AACH, in turn, is typically prepared by adding ammonium bicarbonate to an aluminum sulphate solution. ${ }^{31}$ This process generates a large amount of wastewater containing $\left(\mathrm{NH}_{4}\right)_{2} \mathrm{SO}_{4}$. If AACH could be generated from gibbsite rather than amorphous aluminum hydroxide, an inexpensive sodium aluminate solution could be used to prepare FAA via a precipitation process that does not generate wastewater. Trimm et al. demonstrated that AACH can 
be synthesized from fine amorphous aluminum hydroxide by pumping $\mathrm{CO}_{2}$ into a dilute sodium aluminate solution. This material was found to have a low SSA (from 200 to $300 \mathrm{~m}^{2} \mathrm{~g}^{-1}$ ) after the roasting process. ${ }^{32,33}$ However, there have been few reports of AACH synthesis using gibbsite. Furthermore, FAA with a high SSA of over $500 \mathrm{~m}^{2} \mathrm{~g}^{-1}$ is expected to be obtained from a sodium aluminate solution without wastewater.

In the present study, an inexpensive sodium aluminate solution was used to prepare FAA by promoting a sequential phase evolution from gibbsite to AACH to FAA. The feasibility of changing gibbsite to AACH in an ammonium carbonate solution was initially examined based on thermodynamic calculations. The phase evolution process, along with the resultant particle size distribution (PSD), particle morphology and pore structure, were subsequently characterized by X-ray diffraction (XRD), PSD analysis, scanning electron microscopy (SEM), transmission electron microscopy (TEM) and $\mathrm{N}_{2}$ adsorptiondesorption isotherms. The mechanism associated with the formation of FAA with a high SSA was also studied in detail. In addition, the FAA resulting from this process was employed to remove phosphate from wastewater. The results demonstrate a novel green process for the preparation of FAA with a high SSA and also improve our understanding of the mechanism by which particle aggregation is inhibited.

\section{Experiment}

\subsection{Experimental materials}

Sodium aluminate solution with $\alpha_{\mathrm{k}} 1.45$ (molar ratio of caustic soda $\mathrm{Na}_{2} \mathrm{O}$ to alumina $\mathrm{Al}_{2} \mathrm{O}_{3}$ in sodium aluminate solution) was prepared with aluminum hydroxide and sodium hydroxide (Xilong Chemical Co., Ltd.). $\mathrm{H}_{2} \mathrm{O}_{2},\left(\mathrm{NH}_{4}\right)_{2} \mathrm{CO}_{3}, \mathrm{NH}_{3} \cdot \mathrm{H}_{2} \mathrm{O}$ and $\mathrm{CH}_{3} \mathrm{CH}_{2} \mathrm{OH}$ (Sinopharm Chemical Reagent Beijing Co., Ltd, China), as well as reagents used in analysis were of analytical purity.

\subsection{Experimental}

2.2.1 Preparation of AACH from gibbsite precipitated from sodium aluminate solution. $15 \mathrm{~mL}$ of sodium aluminate solution $\left(C_{\mathrm{Na}_{2} \mathrm{O}}=2.26 \mathrm{~mol} \mathrm{~L}^{-1}, C_{\mathrm{Al}_{2} \mathrm{O}_{3}}=1.57 \mathrm{~mol} \mathrm{~L}^{-1}\right)$ and $400 \mathrm{~mL}$ of deionized water were added into a round flask, $25 \mathrm{~mL}$ of $\mathrm{H}_{2} \mathrm{O}_{2}$ (10 wt\%) was then added at speed of $5 \mathrm{~mL} \mathrm{~min}{ }^{-1}$ to generate a gibbsite seed in vigorous agitation, followed by precipitation of the gibbsite at $50{ }^{\circ} \mathrm{C}$ for $60 \mathrm{~min}$. The fine gibbsite was filtered and washed with boiling deionized water. Afterwards, the fine gibbsite was placed into a flask containing $100 \mathrm{~mL}$ of $\left(\mathrm{NH}_{4}\right)_{2} \mathrm{CO}_{3}$ $\left(1.54 \mathrm{~mol} \mathrm{~L}^{-1}\right)$ solution and $100 \mathrm{~mL}$ of deionized water. AACH was produced at $50{ }^{\circ} \mathrm{C}$ for $24 \mathrm{~h}$ when $\mathrm{pH}$ was maintained at approximately 10.0 with addition ammonia ( $30 \mathrm{wt} \%$ ). AACH was then obtained by centrifugation, washed with deionized water and alcohol, and dried at $60{ }^{\circ} \mathrm{C}$ for $24 \mathrm{~h}$. Finally, FAA was obtained by roasting AACH at different temperature for $180 \mathrm{~min}$. The green economical process in preparing FAA is listed in Fig. 1.

In Fig. 1, the spent liquor (spent sodium aluminate solution) is used to dissolve aluminum hydroxide or bauxite, and the fine gibbsite is then precipitated from the supersaturated sodium aluminate solution, in which caustic soda is recycled. In addition, $\mathrm{CO}_{2}$ and $\mathrm{NH}_{3}$, decomposed from $\mathrm{AACH}$, are transformed into $\left(\mathrm{NH}_{4}\right)_{2} \mathrm{CO}_{3}$ solution, and $\mathrm{AACH}$ is then formed in $\left(\mathrm{NH}_{4}\right)_{2} \mathrm{CO}_{3}$ solution. $\mathrm{CO}_{2}$ and $\mathrm{NH}_{3}$ are also recycled. Therefore, no wastewater and gas will be discharged during the preparation of FAA from sodium aluminate solution.

2.2.2 Removal of phosphate from wastewater. The phosphate solution by dissolving $\mathrm{KH}_{2} \mathrm{PO}_{4}$ into deionized water was used to simulate wastewater containing phosphorus. Afterwards, $100 \mathrm{~mL}$ as-prepared $\mathrm{KH}_{2} \mathrm{PO}_{4}$ solution and $2 \mathrm{~g} \mathrm{~L}^{-1}$ FAA were mixed together at $25{ }^{\circ} \mathrm{C}$, removal of phosphate from wastewater was then studied by static shaking table test.

\subsection{Characterization and methods}

2.3.1 Characterization. Gibbsite, AACH and FAA was identified by X-ray diffraction (XRD, Rigaku TTR-III) with $\mathrm{Cu} \mathrm{K} \alpha$ radiation $(\lambda=0.154056 \mathrm{~nm})$, the applied tube voltage and electric current were $40 \mathrm{kV}$ and $250 \mathrm{~mA}$, respectively. Scan range varied from $10^{\circ}$ to $75^{\circ}$, and the scanning rate of $10^{\circ} \mathrm{min}^{-1}$. PSD was determined using a Mastersizer-2000 (Malvern UK) when sample was dispersed in deionized water by ultrasonic. Morphologies were observed on SEM (JSM-6360LV, JEOL, Japan) and TEM (FEI Tecnai G2 F20, USA). The thermal gravimetric analysis and differential thermal analysis (TG-DTA) measurements were conducted on Thermal Analysis SDT-2960 (USA) with a heating rate of 5,10 and $20^{\circ} \mathrm{C} \mathrm{min}-1$ and up to $800^{\circ} \mathrm{C}$ in an air atmosphere. After powder was pressed into a thin tablet with $0.2 \mathrm{~g}$ sample under $20 \mathrm{MPa}$, the surface properties of alumina, boehmite and AACH were measured by CL200B Contact Angle instrument (Shanghai junlun information technology Co., LTD., China) using the drop method with glycerin, diiodomethane and deionized water, surface tension and free energy were then calculated based on the Owen rule. $\mathrm{N}_{2}$ adsorption-desorption isotherms and pore structure were obtained on an ASAP 2020 (Micromeritics Instruments, USA) nitrogen adsorption apparatus. All samples were degassed at $150{ }^{\circ} \mathrm{C}$ prior to Brunauer-Emmett-Teller (BET) measurements. The BET specific surface area was determined by a multipoint BET method using the adsorption data in the relative pressure $P / P_{0}$ range of $0.05-0.30$.

2.3.2 Methods. The concentration of caustic soda $\left(\mathrm{Na}_{2} \mathrm{O}\right)$ and alumina $\left(\mathrm{Al}_{2} \mathrm{O}_{3}\right)$ in sodium aluminate solution were measured by titration. Phosphate concentration was determined by the molybdate blue spectrophotometric method. ${ }^{34}$ Adsorption capacity $q_{t}$ (eqn (1)) and removal rate of phosphate $\eta$ (\%) (eqn (2)) were calculated according to the following eqn (1) and (2), respectively.

$$
\begin{gathered}
q_{t}=\frac{\left(C_{0}-C_{t}\right) V}{m} \\
\eta(\%)=\frac{C_{0}-C_{t}}{C_{0}} \times 100 \%
\end{gathered}
$$

where $C_{0}$ and $C_{t}$ are the initial and $t$-moment concentration of phosphate in solution $\left(\mathrm{mg} \mathrm{L}^{-1}\right), q_{t}$ represents the $t$-moment 


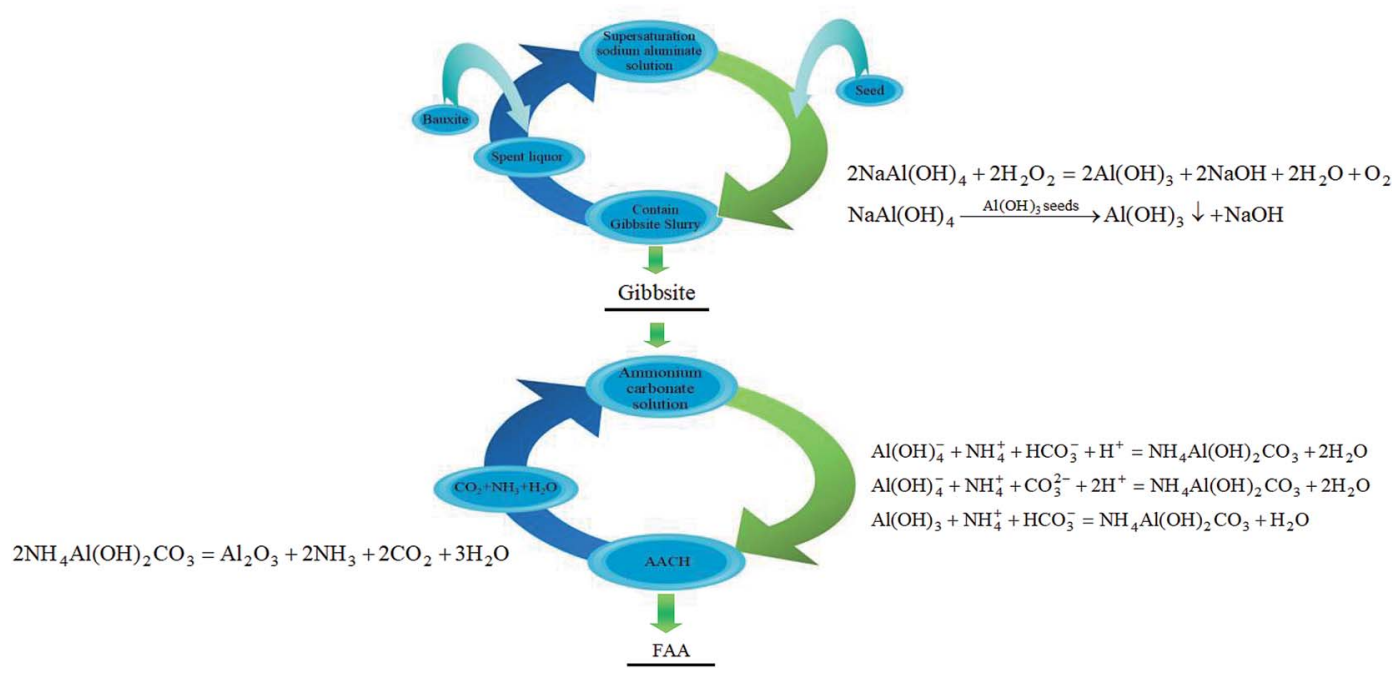

Fig. 1 The green economical approach to prepare FAA with high specific surface area from sodium aluminate solution (containing reaction equation).

adsorption capacity $\left(\mathrm{mg} \mathrm{g}^{-1}\right), m$ stands for adsorbent mass $(\mathrm{g})$, and $V$ is solution volume (L).

\section{Results and discussion}

\subsection{Transformation from gibbsite to AACH}

Gibbsite can be economically precipitated from the supersaturated sodium aluminate solution relative to preparation of amorphous $\mathrm{Al}(\mathrm{OH})_{3}$ by neutralization or hydrolysis. Thus, the possibility of gibbsite changing into AACH was firstly examined through thermodynamic calculation, and the transformation was then verified by experiments.

3.1.1 Reaction behavior of gibbsite in ammonium carbonate solution. Since ammonium carbonate solution is weakly alkaline, $\mathrm{CO}_{3}{ }^{2-}, \mathrm{HCO}_{3}{ }^{-}, \mathrm{OH}^{-}$, and $\mathrm{NH}_{4}{ }^{+}$may exist in the solution. Meanwhile, $\mathrm{CO}_{3}{ }^{2-}, \mathrm{HCO}_{3}{ }^{-}, \mathrm{OH}^{-}$, or $\mathrm{NH}_{4}{ }^{+}$ions may react with aluminum ions. Table 1 lists data of the Gibbs free energy for the above substances. Table 2 presents the possible reaction equations and corresponding reaction constants at $298.15 \mathrm{~K}$.

Ammonium exists in the form of $\mathrm{NH}_{3}, \mathrm{NH}_{4}{ }^{+}$and $\mathrm{NH}_{4^{-}}$ $\mathrm{Al}(\mathrm{OH})_{2} \mathrm{CO}_{3}$ in the system of gibbsite $\left(\mathrm{Al}(\mathrm{OH})_{3}\right)$ changing into $\operatorname{AACH}\left(\mathrm{NH}_{4} \mathrm{Al}(\mathrm{OH})_{2} \mathrm{CO}_{3}\right)$. The total concentration of ammonium in the solution, denoted as $[\mathrm{N}]_{\mathrm{T}}$, was expressed in the following eqn (13) on the basis of the mass balance and reaction formula.

$$
[\mathrm{N}]_{\mathrm{T}}=\left[\mathrm{NH}_{3}\right]+\left[\mathrm{NH}_{4}^{+}\right]+\left[\mathrm{NH}_{4} \mathrm{Al}(\mathrm{OH})_{2} \mathrm{CO}_{3}\right]
$$

As solubility of aluminum hydroxide is minimal in the weakly alkaline $\left(\mathrm{NH}_{4}\right)_{2} \mathrm{CO}_{3}$ solution, little $\mathrm{Al}(\mathrm{OH})_{4}{ }^{-}$exists in the solution. Meanwhile, no corresponding activity coefficient in the $\left(\mathrm{NH}_{4}\right)_{2} \mathrm{CO}_{3}$ solution was reported. Therefore, the ion activity was nearly equal to its concentration. Based on the equilibrium reactions (8)-(12) and mass balance (13), Fig. 2 presents the dependence of $[\mathrm{N}]_{\mathrm{T}}$ on pH at $298.15 \mathrm{~K}$.

Results in Fig. 2 indicated that $\mathrm{NH}_{4} \mathrm{Al}(\mathrm{OH})_{2} \mathrm{CO}_{3}$ could be formed at a pH range from 9.92 to 10.28. Furthermore, raising $\mathrm{pH}$ and $\left(\mathrm{NH}_{4}\right)_{2} \mathrm{CO}_{3}$ concentration widened the region of $\mathrm{NH}_{4}^{-}$ $\mathrm{Al}(\mathrm{OH})_{2} \mathrm{CO}_{3}$ and narrowed the region of AlOOH. Meanwhile, increasing total $\left(\mathrm{NH}_{4}\right)_{2} \mathrm{CO}_{3}$ concentration benefitted $\mathrm{Al}(\mathrm{OH})_{3}$ or $\mathrm{Al}(\mathrm{OH})_{4}{ }^{-}$transformation into $\mathrm{NH}_{4} \mathrm{Al}(\mathrm{OH})_{2} \mathrm{CO}_{3}$ and limited the formation of AlOOH. However, $\mathrm{NH}_{4} \mathrm{Al}(\mathrm{OH})_{2} \mathrm{CO}_{3}$ could be changed into $\mathrm{AlOOH}$ or $\mathrm{Al}(\mathrm{OH})_{4}{ }^{-}$in concentrated alkaline solution.

3.1.2 Phase evolution from gibbsite to AACH to FAA. Fig. 3 shows the XRD patterns obtained on going from gibbsite to AACH to FAA. The well characteristic peaks were assigned to the gibbsite (PDF no. 74-1775) prepared from sodium aluminate solution by seeded precipitation (Fig. 3(a), pattern 1). A new peak at a $2 \theta$ value of $15.31^{\circ}$ in Fig. 3(a) (pattern 2) that was assigned to AACH (PDF no. 52-1138) was found after the gibbsite changed to AACH for 60 min. Many peaks of AACH were then observed after increase in duration (Fig. 3(a), pattern 3 and 4). There results prove that gibbsite can be changed into AACH in $\left(\mathrm{NH}_{4}\right)_{2} \mathrm{CO}_{3}$ solution, which is in well agreement with that in Fig. 2.

Fig. 3(b) shows the phase evolution from gibbsite through AACH and boehmite to FAA. Boehmite (PDF no. 21-1307) was observed during the roasting of AACH at $150{ }^{\circ} \mathrm{C}$, and active alumina $\gamma-\mathrm{Al}_{2} \mathrm{O}_{3}$ (PDF no. 04-0880) was produced during roasting at $500{ }^{\circ} \mathrm{C}$ for $180 \mathrm{~min}$. The $\gamma-\mathrm{Al}_{2} \mathrm{O}_{3}$ evidently had a low degree of crystallization and contained defect sites and high reactive sites, as demonstrated by the broad diffraction peaks in

Table 1 Gibbs free energy of aluminum ions, carbonate ions, or compounds at $298.15 \mathrm{~K}$ (ref. 35-38)

\begin{tabular}{|c|c|c|c|c|c|c|c|}
\hline $\begin{array}{l}\text { Substances } \\
\Delta_{\mathrm{f}} G^{\theta} /\left(\mathrm{kJ} \mathrm{mol}^{-1}\right)\end{array}$ & $\begin{array}{l}\mathrm{AlO}_{2}^{-} \\
-827.48\end{array}$ & $\begin{array}{l}\mathrm{Al}(\mathrm{OH})_{4}^{-} \\
-1305.7\end{array}$ & $\begin{array}{l}\mathrm{Al}(\mathrm{OH})_{3} \\
-1154.01\end{array}$ & $\begin{array}{l}\text { AlOOH } \\
-1831.51\end{array}$ & $\begin{array}{l}\mathrm{NH}_{4}^{+} \\
-79.5\end{array}$ & $\begin{array}{l}\mathrm{HCO}_{3}{ }^{-} \\
-586.77\end{array}$ & $\begin{array}{l}\mathrm{CO}_{3}{ }^{2-} \\
-527.98\end{array}$ \\
\hline
\end{tabular}


Table 2 Reaction equation and their equilibrium constant at $298.15 \mathrm{~K}$ (ref. 39-41) ${ }^{a}$

\begin{tabular}{|c|c|c|}
\hline Serial number & Ions reaction equation & $\lg K$ \\
\hline (1) & $\mathrm{AlO}_{2}^{-}+\mathrm{H}^{+}+\mathrm{H}_{2} \mathrm{O}=\mathrm{Al}(\mathrm{OH})_{3}$ & 15.66 \\
\hline (2) & $\mathrm{Al}(\mathrm{OH})_{4}{ }^{-}+\mathrm{H}^{+}=\mathrm{Al}(\mathrm{OH})_{3}+\mathrm{H}_{2} \mathrm{O}$ & 14.97 \\
\hline (4) & $\left(\mathrm{NH}_{4}\right)_{2} \mathrm{CO}_{3}+\mathrm{H}^{+}=2 \mathrm{NH}_{4}^{+}+\mathrm{HCO}_{3}^{-}$ & 0.99 \\
\hline (5) & $\mathrm{HCO}_{3}^{-}=\mathrm{H}^{+}+\mathrm{CO}_{3}^{2-}$ & 10.33 \\
\hline (6) & $\mathrm{NH}_{3} \cdot \mathrm{H}_{2} \mathrm{O}=\mathrm{NH}_{4}^{+}+\mathrm{OH}^{-}$ & 9.24 \\
\hline (9) & $\mathrm{Al}(\mathrm{OH})_{4}{ }^{-}+\mathrm{NH}_{4}{ }^{+}+\mathrm{CO}_{3}{ }^{2-}+2 \mathrm{H}^{+}=\mathrm{NH}_{4} \mathrm{Al}(\mathrm{OH})_{2} \mathrm{CO}_{3}+2 \mathrm{H}_{2} \mathrm{O}$ & 27.03 \\
\hline (10) & $\mathrm{Al}(\mathrm{OH})_{3}+\mathrm{NH}_{4}^{+}+\mathrm{HCO}_{3}^{-}=\mathrm{NH}_{4} \mathrm{Al}(\mathrm{OH})_{2} \mathrm{CO}_{3}+\mathrm{H}_{2} \mathrm{O}$ & 4.34 \\
\hline (11) & $\mathrm{Al}(\mathrm{OH})_{3}+\mathrm{NH}_{4}^{+}+\mathrm{CO}_{3}{ }^{2-}+\mathrm{H}^{+}=\mathrm{NH}_{4} \mathrm{Al}(\mathrm{OH})_{2} \mathrm{CO}_{3}+\mathrm{H}_{2} \mathrm{O}$ & 14.99 \\
\hline (12) & $\mathrm{NH}_{4} \mathrm{Al}(\mathrm{OH})_{2} \mathrm{CO}_{3}=\mathrm{AlOOH}+\mathrm{NH}_{4}^{+}+\mathrm{HCO}_{3}{ }^{-}$ & 0.155 \\
\hline
\end{tabular}

${ }^{a} \lg K$ for eqn (8)-(12) are obtained according to the following equation $\Delta G_{298}^{\theta}=-R T \ln K$.

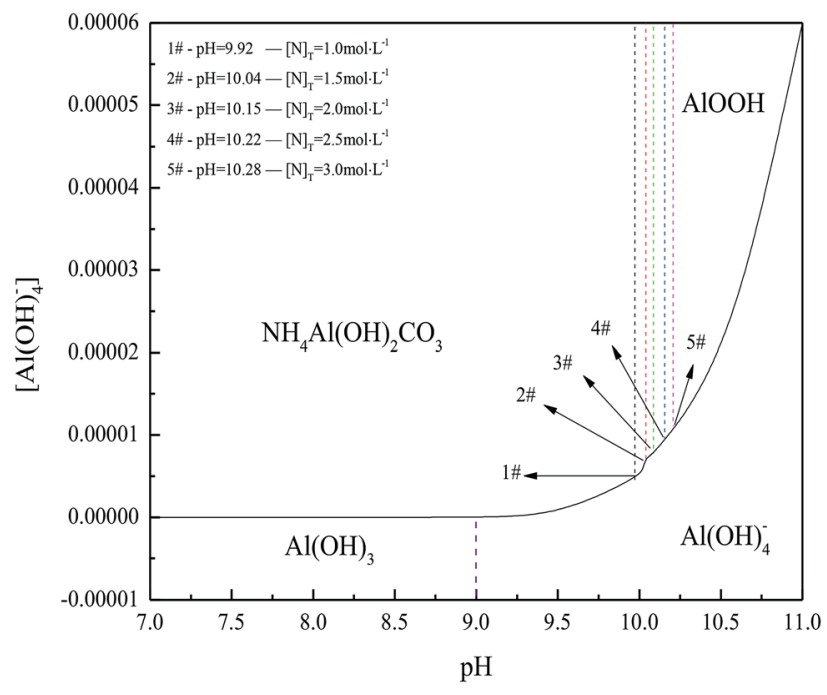

Fig. 2 Phase diagram of aluminum compound in $\left(\mathrm{NH}_{4}\right)_{2} \mathrm{CO}_{3}$ system at 298.15 K. $1 \#-p H=9.92,[N]_{T}=1.0 \mathrm{~mol} \mathrm{~L}^{-1}, 2 \#-\mathrm{pH}=10.04,[\mathrm{~N}]_{\mathrm{T}}=$ $1.5 \mathrm{~mol} \mathrm{~L}^{-1}, 3 \#-\mathrm{pH}=10.15,[\mathrm{~N}]_{\mathrm{T}}=2.0 \mathrm{~mol} \mathrm{~L}^{-1}, 4 \#-\mathrm{pH}=10.22,[\mathrm{~N}]_{\mathrm{T}}=$ $2.5 \mathrm{~mol} \mathrm{~L}^{-1}, 5 \#-\mathrm{pH}=10.28,[\mathrm{~N}]_{\mathrm{T}}=3.0 \mathrm{~mol} \mathrm{~L}^{-1}$.

Fig. 3(b), pattern $3 .^{42}$ Those data demonstrate that $\gamma-\mathrm{Al}_{2} \mathrm{O}_{3}$ is successfully produced by phase evolution from gibbsite to AACH and FAA.

3.1.3 PSDs of gibbsite, AACH and FAA. The particle size of the precursor has a significant effect on the SSA of the FAA, and Fig. 4 presents the PSD curves for the gibbsite, AACH and FAA prepared in this work. It was evident that the PSD plot of the FAA resembled those of the gibbsite and AACH. The mean particle sizes $(d(50))$ of gibbsite, AACH and FAA were 0.586, 0.554 and $0.417 \mu \mathrm{m}$, respectively, confirming that each was the fine powder. Although extensive particle aggregation typically occurs during the powder drying and roasting (or calcining) processes, such aggregation was effectively inhibited in the present work by the phase evolution process to synthesize the FAA.

3.1.4 Morphological structures of gibbsite, AACH and FAA. To further clarify the particle size variations among the gibbsite, AACH and FAA, SEM and TEM images are presented in Fig. 5.
The gibbsite particles in Fig. 5(a) were approximately $0.5 \mu \mathrm{m}$ in size, which was consistent with the results in Fig. 4. After ultrasonication was applied to disperse the gibbsite in anhydrous alcohol (90 W power for $240 \mathrm{~min}$ ), gibbsite particles approximately 30 to $60 \mathrm{~nm}$ in size were found to be aggregated (Fig. 5(b)). Fig. 5(c) showed uniform, fine AACH fibers with lengths of approximately 1.00-1.50 $\mu \mathrm{m}$ and diameters of close to $0.05 \mu \mathrm{m}$. The fact that the well crystallized AACH was readily filtered compared with nano-gibbsite led to inexpensive separation from solid to liquid in slurry. Roasting of the AACH at $500{ }^{\circ} \mathrm{C}$ for 180 min gave FAA particles with fiber-like shapes (Fig. 5(d)) and a similar morphology to the AACH. Many FAA primary particles with sizes less than $30 \mathrm{~nm}$ were also observed, with numerous nanopores having diameters of over $2 \mathrm{~nm}$ scattered throughout the particles.

Thus, particle aggregation during the transformation from gibbsite through AACH to FAA was effectively inhibited. This process allows the economical, environmentally friendly preparation of FAA from a sodium aluminate solution, based on recycling of the spent sodium aluminate solution and the decomposition gases $\mathrm{NH}_{3}$, and $\mathrm{CO}_{2}$ produced during the roasting step.

\subsection{Pore structure of FAA}

The pore structure (pore size, pore volume, and open or closed pore) of the FAA, which is related to its SSA, is affected by the roasting process. Thus, the effects of both the roasting temperature and heating rate were investigated, with the aim of minimizing the particle aggregation.

3.2.1 Effect of roasting temperature on mass loss. Because $\mathrm{H}_{2} \mathrm{O}, \mathrm{CO}_{2}$ and $\mathrm{NH}_{3}$ are generated during the thermal decomposition of $\mathrm{AACH}$, the gas volume produced per unit time, which in turn is related to the heating rate, will determine the FAA pore structure. Fig. 6 provides the thermal gravimetric and differential thermal analysis (TG-DTA) curves obtained from $\mathrm{AACH}$ decomposition at various heating rates.

In Fig. 6, similar TG-DTA curves were acquired at heating rates of 5,10 and $20^{\circ} \mathrm{C} \mathrm{min}{ }^{-1}$. However, increasing the heating rate shifted the onset of thermal decomposition from 195.27 to 

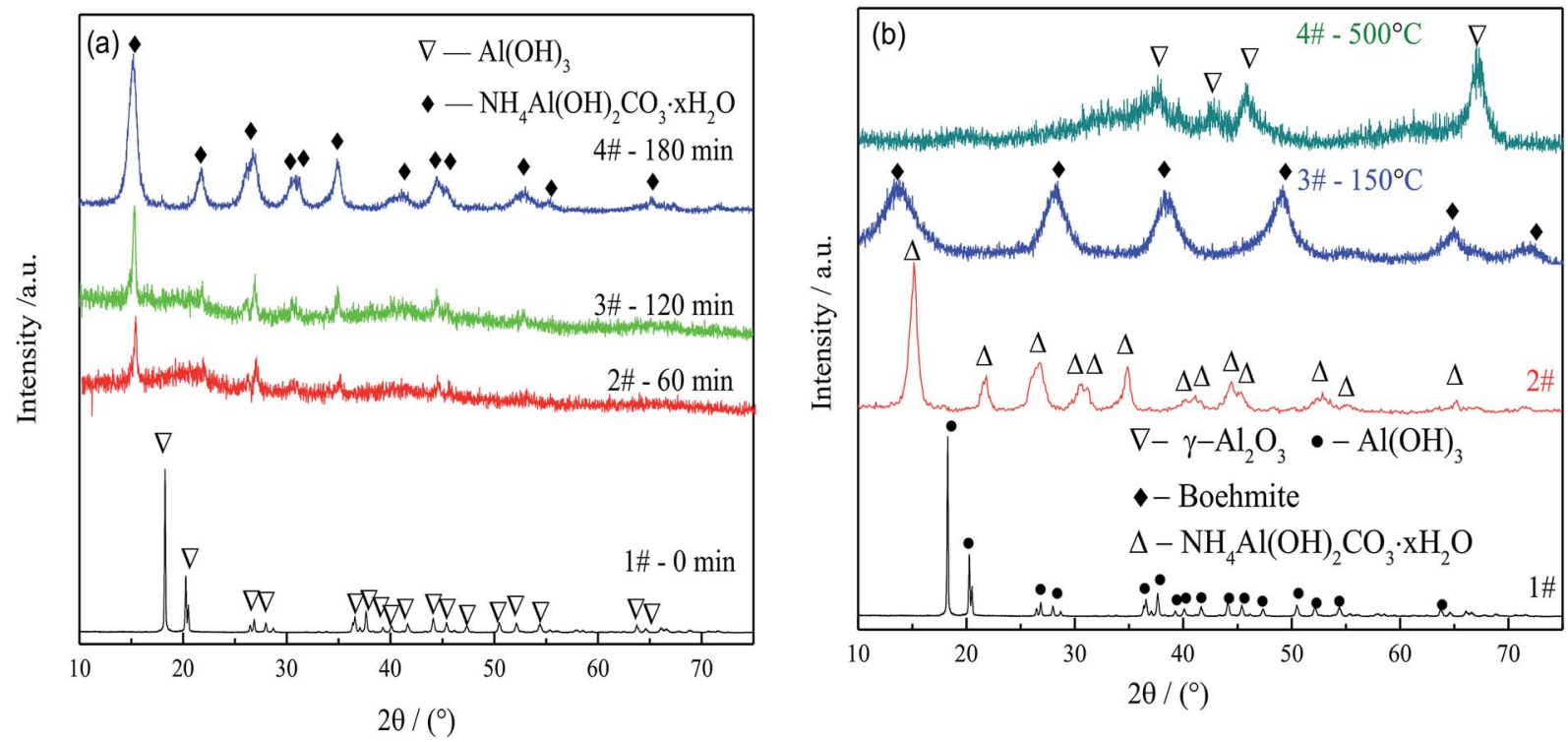

Fig. 3 XRD patterns of (a) AACH synthesized from gibbsite over different time spans and (b) gibbsite, AACH, boehmite and FAA. Gibbsite was precipitated from a sodium aluminate solution $\left(C_{\mathrm{Na}_{2} \mathrm{O}}=2.26 \mathrm{~mol} \mathrm{~L}{ }^{-1}, \mathrm{C}_{\mathrm{Al}_{2} \mathrm{O}_{3}}=1.57 \mathrm{~mol} \mathrm{~L}{ }^{-1}\right)$ at $50{ }^{\circ} \mathrm{C}$ for 65 min, while AACH was produced in ammonium carbonate solution $\left(\mathrm{C}_{\left(\mathrm{NH}_{4}\right)_{2} \mathrm{CO}_{3}=1.54 \mathrm{~mol} \mathrm{~L}}{ }^{-1}\right)$ held at $50{ }^{\circ} \mathrm{C}$ for $180 \mathrm{~min}$. Boehmite was obtained after the AACH was roasted at $150{ }^{\circ} \mathrm{C}$ for $180 \mathrm{~min}$, and FAA was synthesized by roasting the $\mathrm{AACH}$ at $500{ }^{\circ} \mathrm{C}$ for $180 \mathrm{~min}$.

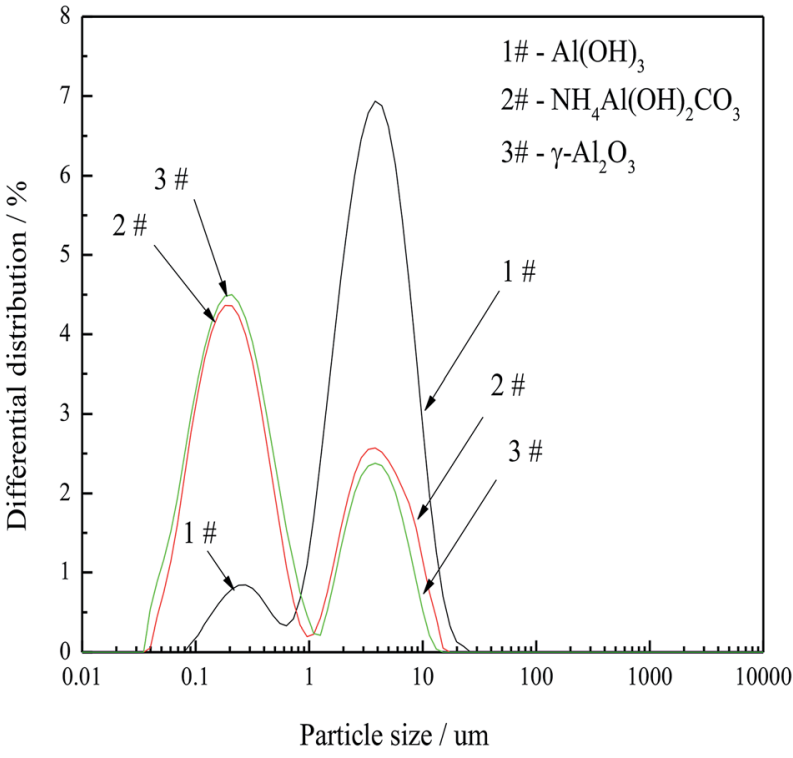

Fig. 4 PSD curves of gibbsite, AACH and FAA. Gibbsite was precipitated from a sodium aluminate solution $\left(\mathrm{C}_{\mathrm{Na}_{2} \mathrm{O}}=2.26 \mathrm{~mol} \mathrm{~L}{ }^{-1}, \mathrm{C}_{\mathrm{Al}_{2} \mathrm{O}_{3}}=\right.$ $1.57 \mathrm{~mol} \mathrm{~L}^{-1}$ ) at $50{ }^{\circ} \mathrm{C}$ for $65 \mathrm{~min}$, while $\mathrm{AACH}$ was produced in ammonium carbonate solution $\left(\mathrm{C}_{\left(\mathrm{NH}_{4}\right)_{2} \mathrm{CO}_{3}=1.54 \mathrm{~mol} \mathrm{~L}}{ }^{-1}\right)$ at $50{ }^{\circ} \mathrm{C}$ for $180 \mathrm{~min}$. The FAA was obtained after AACH roasted at $500{ }^{\circ} \mathrm{C}$ for $180 \mathrm{~min}$.

201.47 to $219.92{ }^{\circ} \mathrm{C}$, while reducing the extent of mass loss. There results suggest that a greater volume of gas will be released per unit time when applying a more rapid heating during the roasting of AACH. A strong endothermic peak appears at $200{ }^{\circ} \mathrm{C}$ in each curve, attributed to the formation of boehmite as an intermediate (in Fig. 3(b)). Increasing the heating rate may accelerate the formation of boehmite because a mass losses of $56.03 \mathrm{wt} \%$ occurred at $20{ }^{\circ} \mathrm{C} \mathrm{min}^{-1}$ comparison to $56.83 \mathrm{wt} \%$ in the form of boehmite from $\mathrm{AACH}$. Moreover, a 1.55-1.85 wt\% mass loss was observed above $500{ }^{\circ} \mathrm{C}$, owing to the formation of $\gamma-\mathrm{Al}_{2} \mathrm{O}_{3} \cdot{ }^{43}$ From those results, the AACH appears to have decomposed according to the following series of reactions.

$$
\begin{aligned}
\mathrm{NH}_{4} \mathrm{Al}(\mathrm{OH})_{2} \mathrm{CO}_{3} \triangleq & \mathrm{AlOOH}(\text { boehmite })+\mathrm{NH}_{3} \uparrow+\mathrm{CO}_{2} \uparrow \\
& +\mathrm{H}_{2} \mathrm{O} \uparrow
\end{aligned}
$$

$$
2 \mathrm{AlOOH} \triangleq \mathrm{Al}_{2} \mathrm{O}_{3} \text { (amorphous) }+\mathrm{H}_{2} \mathrm{O} \uparrow
$$

$$
\mathrm{Al}_{2} \mathrm{O}_{3} \text { (amorphous) } \triangleq \gamma-\mathrm{Al}_{2} \mathrm{O}_{3}
$$

AlOOH was interestingly found during the transformation of AACH into FAA. Its surface property and water mass loss differed from those of $\mathrm{Al}(\mathrm{OH})_{3}\left(2 \mathrm{Al}(\mathrm{OH})_{3}=\mathrm{Al}_{2} \mathrm{O}_{3}+3 \mathrm{H}_{2} \mathrm{O}\right),{ }^{44,45}$ formation of boehmite may mitigate the hard aggregation of particles in roasting process.

3.2.2 Effect of roasting temperature on contact angle and surface energy. Contact angle measurements are often used to evaluate surface properties such as hydrophilicity, hydrophobicity and surface free energy. Thus, the extent of particle aggregation on going from $\mathrm{AACH}$ to $\mathrm{AlOOH}$ to FAA was discussed by determining the contact angles of $\mathrm{AACH}, \mathrm{AlOOH}$ and FAA with similar PSDs. The solid surface energy of each material was also estimated using Owen's method. ${ }^{\mathbf{4 6}}$ Table 3 displays the resulting data.

The results in Table 3 indicated that the contact angles tended to vary significantly when glycerol, diiodomethane and 

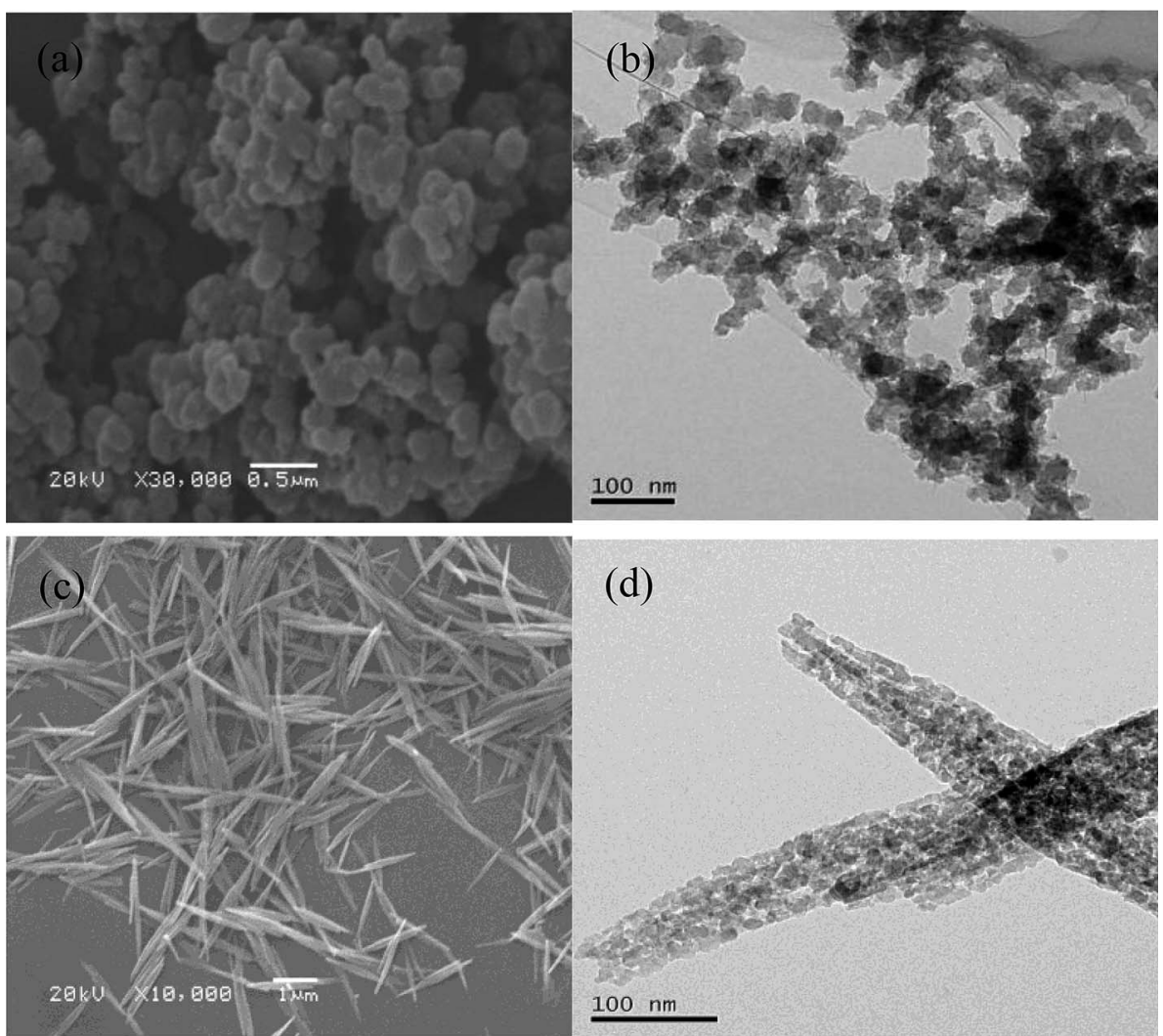

Fig. 5 SEM and TEM images of (a and b) gibbsite, (c) AACH and (d) FAA. Gibbsite was precipitated from a sodium aluminate solution ( $C_{\mathrm{Na}_{2} \mathrm{O}}=$ $\left.2.26 \mathrm{~mol} \mathrm{~L}^{-1}, \mathrm{C}_{\mathrm{Al}_{2} \mathrm{O}_{3}}=1.57 \mathrm{~mol} \mathrm{~L}-1\right)$ at $50^{\circ} \mathrm{C}$ for $65 \mathrm{~min}$, while $\mathrm{AACH}$ was produced in ammonium carbonate solution $\left(\mathrm{C}_{\left(\mathrm{NH}_{4}\right)_{2} \mathrm{CO}}=1.54 \mathrm{~mol} \mathrm{~L}-1\right)$ at $50{ }^{\circ} \mathrm{C}$ for $180 \mathrm{~min}$. The FAA was obtained after $\mathrm{AACH}$ roasted at $500{ }^{\circ} \mathrm{C}$ for $180 \mathrm{~min}$.

water were acted as the liquid phase. Elevating the temperature gradually decreased the contact angle with glycerol, while the contact angles of AACH and boehmite remained nearly constant with diiodomethane. In contrast, the contact angle initially increased and then decreased with increasing temperature when using water (Table $3\left(\theta_{3}\right)$ ). These data suggest that the hydrophobicity increases in the order of AACH $>$ boehmite $>$ FAA, thereby preventing particle aggregation. In addition, the solid surface energy remained essentially constant at roasting temperatures ranging from 150 to $500{ }^{\circ} \mathrm{C}$ but significantly increased at $800{ }^{\circ} \mathrm{C}$. This finding is in agreement with the minimal increase in particle size on going from AACH to FAA (Fig. 4). This finding reveals that the interface energy of the powder is dependent on particle size.

3.2.3 Effect of roasting temperature on the pore diameter distribution of FAA. The functionality and SSA of FAA are both dependent on its pore structure. ${ }^{48}$ Because the gas volume release varies with the roasting temperature, the pore structure will also be expected to vary along with the AACH thermal decomposition temperature. Fig. 7 provides the $\mathrm{N}_{2}$ adsorptiondesorption isotherms and pore size distribution date obtained at specific roasting temperatures.
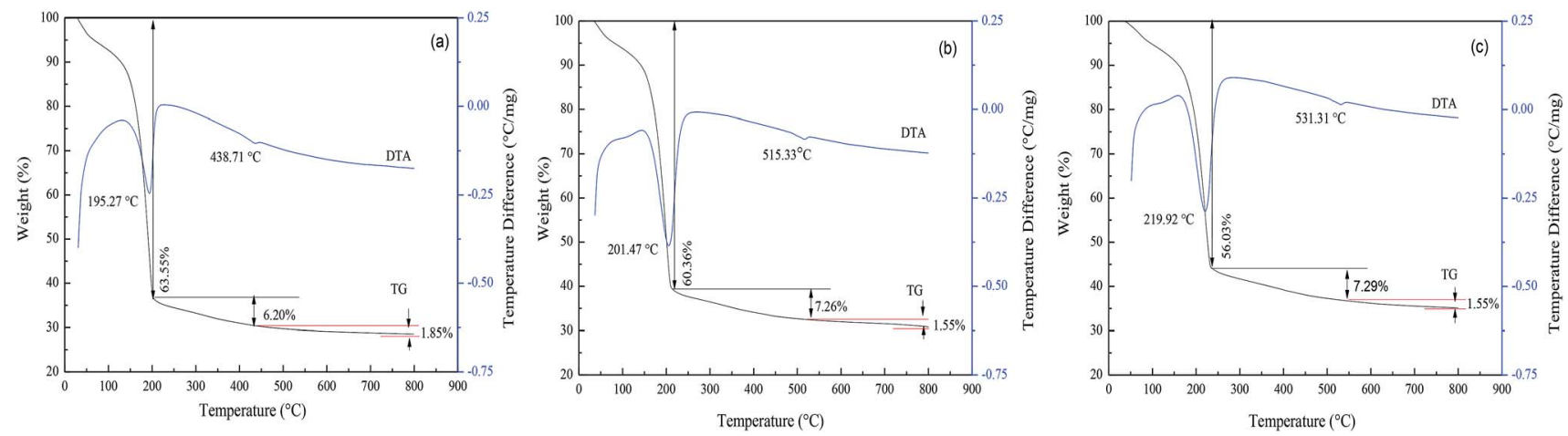

Fig. 6 TG-DTA curves obtained from AACH at heating rates of (a) 5, (b) 10 and (c) $20^{\circ} \mathrm{C} \mathrm{min}{ }^{-1}$. Gibbsite was precipitated from a sodium aluminate solution $\left(\mathrm{C}_{\mathrm{Na}_{2} \mathrm{O}}=2.26 \mathrm{~mol} \mathrm{~L}^{-1}, \mathrm{C}_{\mathrm{Al}_{2} \mathrm{O}_{3}}=1.57 \mathrm{~mol} \mathrm{~L}^{-1}\right)$ at $50^{\circ} \mathrm{C}$ for $65 \mathrm{~min}$, while AACH was produced in ammonium carbonate solution $\left(\mathrm{C}_{\left(\mathrm{NH}_{4}\right)_{2} \mathrm{CO}_{3}}=1.54 \mathrm{~mol} \mathrm{~L}^{-1}\right)$ at $50{ }^{\circ} \mathrm{C}$ for $180 \mathrm{~min}$. 
Table 3 Surface properties of the original aluminum oxide and its hydrate formed by the roasting process ${ }^{a}$

\begin{tabular}{lllllllll}
\hline & 1\#-Al(OH) & 2\#-AACH & 3\#-boehmite & 4\#-FAA-R2 & 5\#-FAA-R3 & 6\#-FAA-R4 & 7\#-FAA-R5 & 8\#-FAA-R8 \\
\hline Roasting temperature $\left({ }^{\circ} \mathrm{C}\right)$ & - & - & 150 & 200 & 300 & 400 & 500 \\
$\theta_{1}$ (glycerol, ${ }^{\circ}$ ) & 63.78 & 62.71 & 50.23 & 47.55 & 30.14 & 27.30 & 15.45 & 1400 \\
$\theta_{2}\left(\right.$ diiodomethane, $\left.^{\circ}\right)$ & 38.92 & 36.59 & 36.95 & 27.19 & 23.09 & 21.62 & 14.28 & 13.52 \\
$\theta_{3}\left(\right.$ water, $\left.^{\circ}\right)$ & 28.34 & 30.82 & 33.79 & 53.45 & 25.14 & 22.62 & 20.73 & 18.10 \\
$\gamma_{\mathrm{s}}\left(\mathrm{mJ} \mathrm{m}^{-2}\right)$ & 40.26 & 41.37 & 44.67 & 47.81 & 44.82 & 44.93 & 45.50 & 61.97
\end{tabular}

${ }^{a} 0.2 \mathrm{~g}$ sample was pressed into a thin tablet under $20 \mathrm{MPa}$ for $1 \mathrm{~min} .{ }^{47} 1 \#-\mathrm{Al}(\mathrm{OH})_{3}, 2 \#-\mathrm{AACH}, 3 \#$-boehmite, roasting AACH at $150{ }^{\circ} \mathrm{C}$ for $180 \mathrm{~min}, 4 \#-$ FAA-R2, roasting AACH at $200^{\circ} \mathrm{C}$ for $180 \mathrm{~min}, 5 \#-F A A-R 3$, roasting AACH at $300{ }^{\circ} \mathrm{C}$ for $180 \mathrm{~min}, 6 \#-F A A-R 4$, roasting AACH at $400{ }^{\circ} \mathrm{C}$ for $180 \mathrm{~min}, 7 \#-$ FAA-R5, roasting AACH at $500{ }^{\circ} \mathrm{C}$ for $180 \mathrm{~min}, 8 \#-F A A-R 8$, roasting AACH at $800{ }^{\circ} \mathrm{C}$ for $180 \mathrm{~min}$.

Fig. 7(a) and (b) present the $\mathrm{N}_{2}$ adsorption-desorption isotherms of FAA roasted at various temperatures. Type IV curves were obtained at 200,300 and $800{ }^{\circ} \mathrm{C}$, as well as type H1 hysteresis loop according to the IUPAC classification system, confirming the presence of open mesopores. In contrast, type I curves were generated by the $\mathrm{AACH}$ roasted at 400 and $500{ }^{\circ} \mathrm{C}$, primarily due to the presence of $\left(\mathrm{NH}_{4}\right)_{2} \mathrm{CO}_{3}$ in water in the capillaries. These samples also produced type $\mathrm{H} 4$ hysteresis loops consistent with narrow pores.
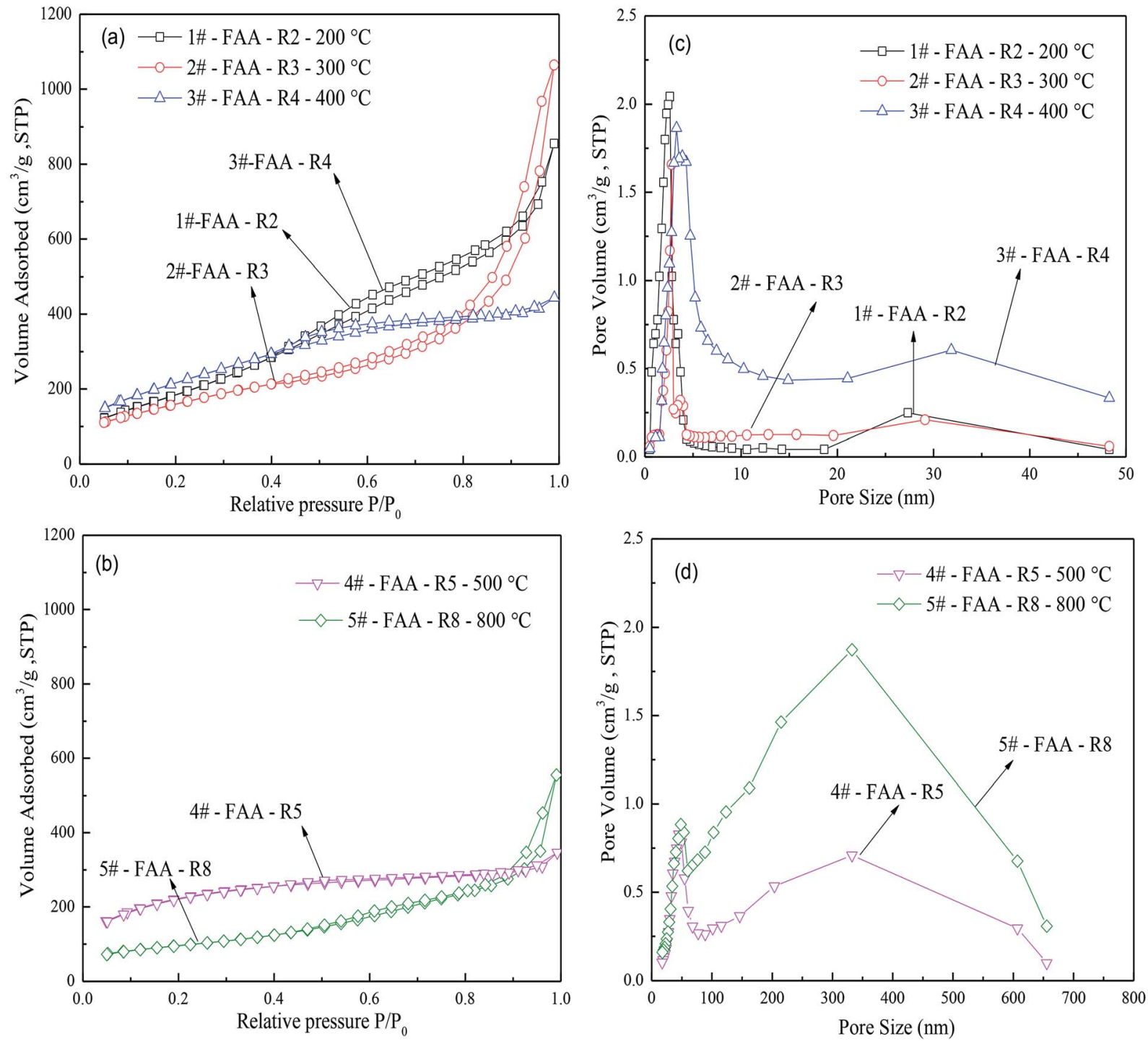

Fig. 7 The effect of roasting temperature on ( $a$ and b) $\mathrm{N}_{2}$ adsorption-desorption isotherms and (c and d) pore diameter distribution. STP: standard temperature and pressure. Gibbsite was precipitated from a sodium aluminate solution $\left(\mathrm{C}_{\mathrm{Na}_{2} \mathrm{O}}=2.26 \mathrm{~mol} \mathrm{~L}^{-1}, \mathrm{C}_{\mathrm{Al}_{2} \mathrm{O}_{3}}=1.57 \mathrm{~mol} \mathrm{~L}{ }^{-1}\right)$ at $50{ }^{\circ} \mathrm{C}$ for $65 \mathrm{~min}$, while $\mathrm{AACH}$ was produced in ammonium carbonate solution $\left(\mathrm{C}_{\left(\mathrm{NH}_{4}\right)_{2} \mathrm{CO}_{3}}=1.54\right.$ mol L $\left.\mathrm{L}^{-1}\right)$ at $50{ }^{\circ} \mathrm{C}$ for 180 min. $\mathrm{FAA}$ was synthesized by roasting the $\mathrm{AACH}$ roasted at different temperature for $180 \mathrm{~min}$. 
Table 4 Pore characteristics of AACH synthesized via thermal decomposition at various heating rates

\begin{tabular}{|c|c|c|c|c|c|c|c|}
\hline \multirow[b]{2}{*}{ Samples } & \multirow[b]{2}{*}{$\begin{array}{l}\text { Temperature } \\
\left({ }^{\circ} \mathrm{C}\right)\end{array}$} & \multicolumn{2}{|c|}{ Surface area $(\mathrm{BET})\left(\mathrm{m}^{2} \mathrm{~g}^{-1}\right)$} & \multicolumn{2}{|c|}{ Total pore volume $\left(\mathrm{cm}^{3} \mathrm{~g}^{-1}\right)^{a}$} & \multicolumn{2}{|c|}{ Average pore diameter $(\mathrm{nm})^{b}$} \\
\hline & & Rapid heating rate ${ }^{c}$ & Slow heating rate ${ }^{d}$ & $\begin{array}{l}\text { Rapid heating } \\
\text { rate }\end{array}$ & $\begin{array}{l}\text { Slow heating } \\
\text { rate }\end{array}$ & $\begin{array}{l}\text { Rapid heating } \\
\text { rate }\end{array}$ & $\begin{array}{l}\text { Slow heating } \\
\text { rate }\end{array}$ \\
\hline 1\#-FAA-R2 & 200 & 982.52 & 771.41 & 0.55 & 0.28 & 2.44 & 2.54 \\
\hline 2\#-FAA-R3 & 300 & 1088.72 & 925.61 & 0.56 & 0.45 & 2.80 & 2.85 \\
\hline 3\#-FAA-R4 & 400 & 813.23 & 618.68 & 1.32 & 0.54 & 7.17 & 4.43 \\
\hline
\end{tabular}

${ }^{a}$ Single point total pore volume of pores at $P / P_{0}=0.99 .{ }^{b}$ Estimated using the BJH desorption branch of the isotherm. ${ }^{c}$ Rapid heating rate: sample was roasted by a rapid heating rate $\left(20^{\circ} \mathrm{C} \mathrm{min}{ }^{-1}\right)$ from $200{ }^{\circ} \mathrm{C}$ to a given temperature in muffle furnace. ${ }^{d}$ Slow heating rate: sample was roasted according to heating rate of $5{ }^{\circ} \mathrm{C} \min ^{-1}$ from $100{ }^{\circ} \mathrm{C}$ to in muffle furnace.

In Fig. 7(c) and (d), two peaks of pore diameter size were found. Numerous mesopores and few macropores in FAA would promote its functioning as an adsorbent because there pores can provide efficient transportation pathways to molecules. ${ }^{49-51}$ Increasing the temperature from 200 to $800{ }^{\circ} \mathrm{C}$ enlarged the pore diameters, while smaller pores $(2-30 \mathrm{~nm})$ were correspondingly disappeared. There results suggest that smaller pores are preferentially destroyed during thermal decomposition of the $\mathrm{AACH}$, and that the appearance of large pores can be inhibit particle aggregation due to great capillary pressure.

3.2.4 Variations in capillary pressure at different roasting temperatures. To obtain additional information regarding particle aggregation during the roasting process, the capillary pressures (static pressure) were calculated according to the capillary pressure equation $P_{\mathrm{c}}=2 \sigma \cos \theta / r$, using the data in Tables 3 and 4, as well as in Fig. 6 and 7. Capillary pressures (dynamic pressure) were also calculated using the van der Waals equation of state, based on the data in Fig. 6(c). Fig. 8 plots the capillary pressures as functions of the roasting temperature.

There data showed that the capillary pressure was reduced from 46.56 to $2.65 \mathrm{MPa}$ when the roasting temperature was increased from 200 to $400{ }^{\circ} \mathrm{C}$, because large amounts of $\mathrm{NH}_{3}$ and $\mathrm{CO}_{2}$ filled the mesopores after decomposition of the AACH. Accordingly, the high capillary pressure prevented mesopore from collapse, leading to minimal particle aggregation and numerous open mesopores. Although the heating rate of the thermal analysis instrument (SDT-2960) was limited, additional increases in the heating rate would be expected to further increase the amount of gas released per unit time. Consequently, the pressure in the capillary (as shown in curve 1 in Fig. 8) was increased (relative to that in curve 2 in Fig. 8). Thus, a rapid heating rate, favoring the inhibition of particle aggregation, was adopted in the following experiments.

In addition, the $\mathrm{NH}_{3}$ gas generated in this process produced a weakly alkaline solution in the capillary that was conducive to the formation of AlOOH (Fig. 1) instead of $\mathrm{Al}(\mathrm{OH})_{3}$. The data in Table 3 also showed that boehmite was more hydrophobic than gibbsite $\left(\mathrm{Al}(\mathrm{OH})_{3}\right)\left(\right.$ In Table $3 \theta_{\text {AlOOH }}=33.79^{\circ}>\theta_{\mathrm{Al}(\mathrm{OH})_{3}}=$ $\left.28.34^{\circ}\right)$. This finding suggests that the formation of boehmite contributes to the inhibition of aggregation during the AACH roasting process.

3.2.5 Effect of heating rate on pore structure. Particle aggregation was further inhibited by the generation of more

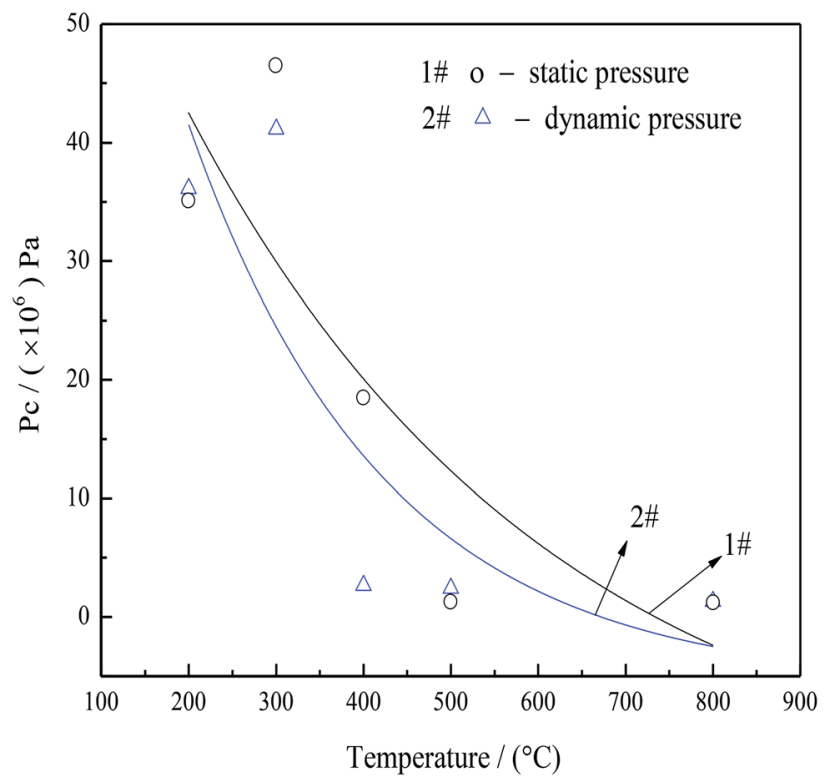

Fig. 8 Static $(1 \#)^{a}$ and dynamic $(2 \#)^{b}$ capillary pressure in pore structures as functions of roasting temperatures. ${ }^{a}$ Calculated according to the equation, $P_{\mathrm{c}}=2 \sigma \cos \theta / r^{52}$ Where $P_{\mathrm{c}}$ is the capillary pressure $(\mathrm{Pa}), \sigma$ is the interfacial tension of the interface $\left(\mathrm{mN} \mathrm{m}^{-1}\right), \theta$ is the contact angle $\left({ }^{\circ}\right), r$ is the pore diameter size $(\mathrm{m}) .{ }^{b} \mathrm{Calculated}$ according to the equation, $\left(P+a / V_{0}{ }^{2}\right)\left(V_{0}-b\right)=R T^{53,54}$ Where $P$ is the gas pressure $(\mathrm{Pa}), a$ and $b$ are species-dependent critical parameters, $V_{0}$ is a gas of the molar volume $(\mathrm{L}), R$ is the gas constant $(R=8.314 \mathrm{~J}$ $\left.(\mathrm{mol} \mathrm{K})^{-1}\right), T$ is the real temperature $\left({ }^{\circ} \mathrm{C}\right) . V_{0}$ was calculated according to mass loss in Fig. 6(c).

$\mathrm{NH}_{3}$ and $\mathrm{CO}_{2}$ over an extremely short time compared to decomposition at a heating rate of $5{ }^{\circ} \mathrm{C} \mathrm{min}^{-1}$ in Fig. 6. A rapid heating rate was therefore employed to obtain FAA with a superhigh SSA. Table 4 summarizes the pore structures (surface area, pore volume and pore diameter) in AACH obtained when various roasting temperature and heating rates were adopted.

Elevating the temperature (in Table 4) increased the average pore size and pore volume of the FAA, while reducing the BET surface area. A rapid heating rate also significantly increased the FAA surface area and total pore volume relative to those obtained using a low heating rate of $5{ }^{\circ} \mathrm{C} \mathrm{min}^{-1}$. Surprisingly, the maximum alumina BET surface area was $1088.72 \mathrm{~m}^{2} \mathrm{~g}^{-1}$ at 

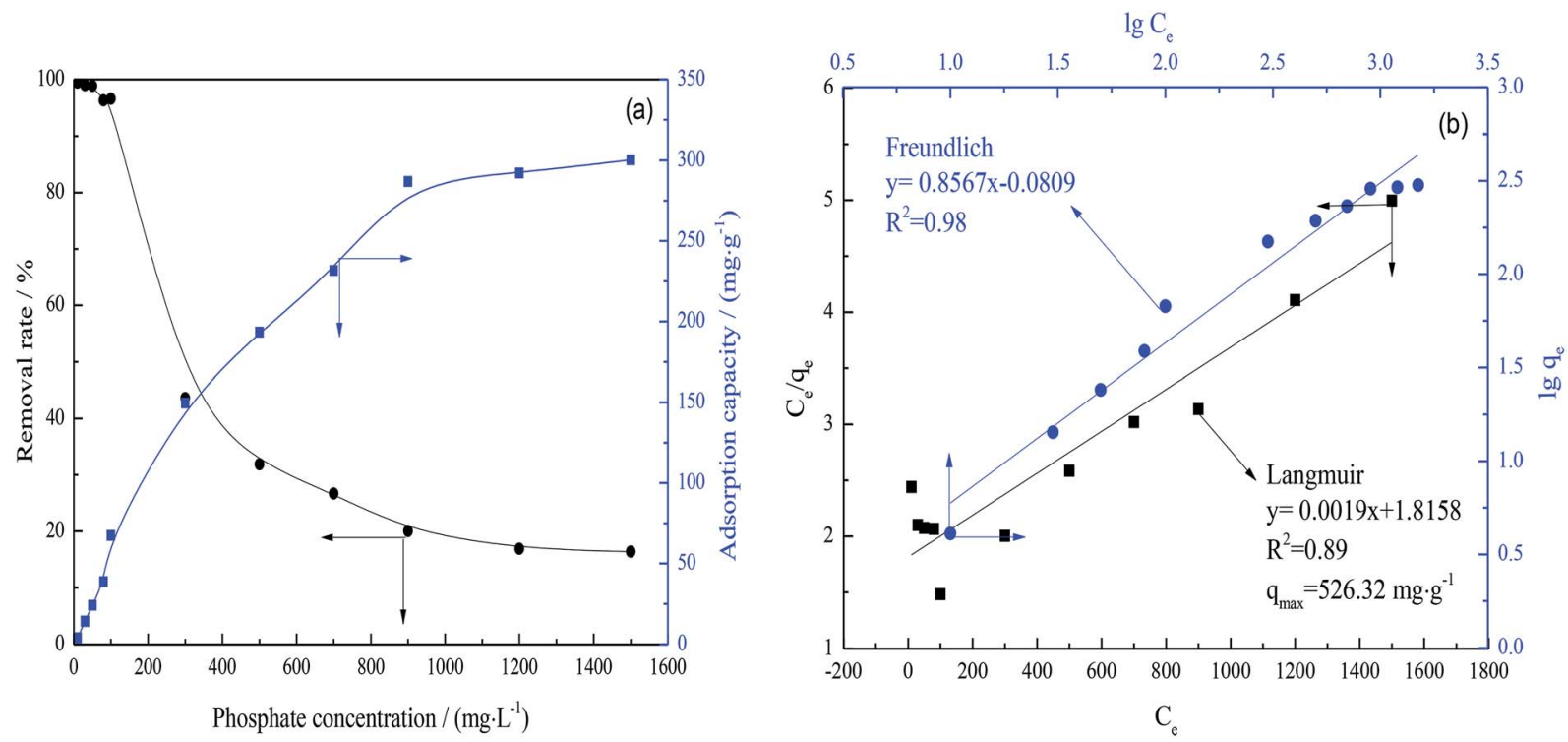

Fig. 9 (a) Adsorption capacity and removal rate as functions of phosphate concentration and (b) fitting results by Langmuir and Freundlich isothermal adsorption models. For the adsorption of phosphate, $0.2 \mathrm{~g}$ FAA (FAA-R5, rapid heating rate) and $100 \mathrm{~mL}$ phosphate solution were added into flask at $\mathrm{pH}$ of 5.0. Removal of phosphate from solution was carried out at $25^{\circ} \mathrm{C}$ with agitation of $150 \mathrm{rpm}$ and contact time $10 \mathrm{~h}$.

$300{ }^{\circ} \mathrm{C}$ when applying a rapid heating rate. This value is much greater than values obtained for nano-alumina produced by solgel, neutralization or hydrolysis. ${ }^{20}$ Roasting the $\mathrm{AACH}$ for $180 \mathrm{~min}$ at a rapid heating rate achieved SSA values of 722.59 and $336.43 \mathrm{~m}^{2} \mathrm{~g}^{-1}$ at 500 and $800{ }^{\circ} \mathrm{C}$, respectively, both of which are also significantly greater than values for fine alumina and nano-alumina. ${ }^{21,22}$ There data demonstrate that the heating rate is closely correlated with the pore structure, total pore volume and average pore diameter.

Based on the above, FAA having a $d(50)$ of $0.417 \mu \mathrm{m}$ with a super-high SSA, a large amount of open mesopores and minimal aggregation is attributed to high capillary pressure, the formation of boehmite as an intermediate and the low surface energy of the particles.

\subsection{Efficient removal of phosphate from wastewater with FAA}

The as-prepared FAA, having plentiful open mesopores, represents an excellent adsorbent for the purification of wastewater. Thus, this FAA was used to efficiently remove phosphate from wastewater. Fig. 9(a) presents the removal rates and adsorption capacities for various solutions, while Fig. 9(b) plots the fitting of the data based on isothermal Langmuir and Freundlich adsorption models.

Fig. 9(a) confirmed that the adsorption capacity of the FAA increased rapidly along with the phosphate concentration at concentrations less than $900 \mathrm{mg} \mathrm{L}^{-1}$ and then increased slowly. There data suggest that the phosphate uptake was primarily due to physisorption rather than chemisorption. Increases in the phosphate concentration at a constant FAA load reduced the removal rate. The FAA was found to exhibit an absorption capacity of $300.28 \mathrm{mg} \mathrm{g}^{-1}$ at equilibrium, significantly greater than the $49.67 \mathrm{mg} \mathrm{g}^{-1}$ achieved with nano-alumina. ${ }^{55}$
From Fig. 9(b), the data were in well agreement with the Freundlich isotherm model, ${ }^{56,57}$ suggesting that multilayer and monolayer adsorption occur simultaneously on the FAA surface. The maximum theoretical phosphate adsorption capacity for the FAA was $526.32 \mathrm{mg} \mathrm{g}^{-1}$ according to the $q_{\mathrm{m}}$ calculated from the Langmuir model. The efficient adsorption of phosphate by this material is attributed to its high SSA and plentiful open mesopores. These data also suggest that this FAA could be employed for the efficient purification of wastewater.

\section{Conclusions}

(1) FAA was prepared via a green, economical process involving phase evolution from gibbsite through AACH to FAA. Increase in both the $\mathrm{pH}$ and $\left(\mathrm{NH}_{4}\right)_{2} \mathrm{CO}_{3}$ concentration promoted the transition of gibbsite to AACH. In this process, fine gibbsite was precipitated from a saturated sodium aluminate solution, followed by AACH preparation from a $\left(\mathrm{NH}_{4}\right)_{2} \mathrm{CO}_{3}$ solution and the subsequent synthesis of FAA by roasting the AACH.

(2) The particle size remained nearly unchanged in the transformation from gibbsite to AACH to FAA. However, increasing the roasting temperature increased the average pore diameter and pore volume while reducing the SSA. A rapid heating rate increased the BET surface area and pore volume, such that the FFA SSA reached $1088.72 \mathrm{~m}^{2} \mathrm{~g}^{-1}$ after heating at $300{ }^{\circ} \mathrm{C}$ for $180 \mathrm{~min}$.

(3) The particle aggregation was effectively inhibited by the formation of boehmite as an intermediate and by the interface hydrophobicity and high capillary pressure during phase evolution from gibbsite to AACH to FAA. High capillary pressure, plentiful open mesopores and inhibition of aggregation all contributed to the super-high SSA of the FAA. 
(4) The adsorption capacity of the FAA for phosphate from wastewater was as high as $300.28 \mathrm{mg} \mathrm{g}^{-1}$, which reflects the high SSA and open mesopores of this material.

\section{Conflicts of interest}

There are no conflicts to declare.

\section{Acknowledgements}

The authors gratefully acknowledge the financial support from the National Natural Science Foundation of China (No. 51874366), and project (FA2017029) supported by Science and Technology Program of Chongzuo, China.

\section{References}

1 R. Lafficher, M. Digne, F. Salvatori, M. Boualleg, D. Colson and F. Puel, J. Cryst. Growth, 2017, 468.

2 E. Boresella, S. Botti, R. Giorgi, S. Martelli, S. Turtù and G. Zappa, Appl. Phys. Lett., 1993, 63(10), 1345-1347.

3 Z. R. Hesabi, H. R. Hafizpour and A. Simchi, J. Mater. Sci. Eng. A, 2007, 454(16), 89-98.

4 X. Shi, C. Yang, L. Zhang, Z. Lu, Y. Zhu, D. Y. Tang, C. Cui and H. B. Zeng, J. Nanomater., 2014, (14), 1.

5 J. Aguado, J. M. Escola, M. C. Castro and B. Paredes, Microporous Mesoporous Mater., 2005, 83(1), 181-192.

6 G. Lee, C. Chen, S. T. Yang and W. S. Ahn, Microporous Mesoporous Mater., 2010, 127(1), 152-156.

7 E. Ponthieu, E. Payen and J. Grimblot, J. Non-Cryst. Solids, 1992, 147-148, 598-605.

8 M. Yada, M. Machida and T. Kijima, Chem. Commun., 1996, 36(6), 769-770.

9 M. Yada, H. Hiyoshi, K. Ohe, M. Machida and T. Kijima, Inorg. Chem., 1997, 36(24), 5565-5569.

10 M. Yada, H. Kitamura, M. Machida and T. Kijima, Langmuir, 1997, 13(20), 5252-5257.

11 Y. Chang, Z. Ling, Y. Li and X. Hu, Electrochim. Acta, 2013, 93, 241-247.

12 X. Liu, Y. Wei, D. Jin and W. H. Shih, Mater. Lett., 2000, 42(3), 143-149.

13 W. El-Nadjar, M. Bonne, E. Trela, L. Rouleau, A. Mino, S. Hocine, E. Payen, C. Lancelot, C. Lamonier, P. Blanchard, X. Courtois, F. Can, D. Duprez and S. Royer, Microporous Mesoporous Mater., 2012, 158(8), 88-98.

14 W. Deng, M. W. Toepke and B. H. Shanks, Adv. Funct. Mater., 2010, 13(1), 61-65.

15 H. C. Lee, H. J. Kim, H. R. Chang, H. L. Kyung, J. S. Lee and S. H. Chung, Microporous Mesoporous Mater., 2005, 79(1), 6168.

16 H. Fischer, C. Niedhart, N. Kaltenborn, A. Prange, R. Marx, F. Niethard and R. Telle, Biomaterials, 2005, 26(31), 61516157.

17 N. Kaltenborn, M. Sax, F. A. Müller, L. Müller, H. Dieker, A. Kaiser, R. Telle and H. Fischer, J. Am. Ceram. Soc., 2010, 90(5), 1644-1646.
18 W. Q. Cai, H. Q. Li and Y. Zhang, Mater. Chem. Phys., 2006, 96(1), 136-139.

19 W. Ling and I. K. Lloyd, J. Am. Ceram. Soc., 2010, 74(11), 2934-2936.

20 T. M. Sullivan, US Pat., 5238669 A, 1993.

21 L. Bokobza and J. P. Chauvin, Polymer, 2005, 46(12), 41444151.

22 H. C. Lee, H. J. Kim, H. R. Chang, K. H. Lee, J. S. Lee and S. H. Chung, Microporous Mesoporous Mater., 2005, 79(1), 61-68.

23 Y. Li, J. Liu and Z. Jia, Mater. Lett., 2006, 60(29), 3586-3590.

24 Z. Zhu, H. Liu, H. Sun and D. Yang, Microporous Mesoporous Mater., 2009, 123(1), 39-44.

25 J. C. Ray, K. S. You, J. W. Ahn and W. S. Ahn, Microporous Mesoporous Mater., 2007, 100(1-3), 183-190.

26 J. H. Kim, K. Y. Jung, K. Y. Park and S. B. Cho, Microporous Mesoporous Mater., 2010, 128(1-3), 85-90.

27 N. Cruise, K. Jansson and K. Holmberg, J. Colloid Interface Sci., 2001, 241(2), 527-529.

28 M. I. F. Macêdo, C. C. Osawa and C. A. Bertran, J. Sol-Gel Sci. Technol., 2004, 30(3), 135-140.

29 B. Xu, T. Xiao, Z. Yan, X. Sun, J. Sloan, S. L. González-Cortés, F. Alshahrani and M. L. H. Green, Microporous Mesoporous Mater., 2006, 91(1), 293-295.

30 G. H. Liu, G. Y. Wu, W. Chen, X. B. Li, Z. H. Peng, Q. S. Zhou and T. G. Qi, Hydrometallurgy, 2018, 176, 253-259.

31 O. Yong-Taeg, S. W. Kim and D. C. Shin, Colloids Surf., A, 2008, 313(9), 415-418.

32 E. R. Mardis, L. Ding, M. D. Mclellan and K. Chen, N. Engl. J. Med., 2009, 361(11), 1058-1066.

33 D. L. Trimm and A. Stanislaus, Appl. Catal., 1986, 21(2), 215238.

34 J. Xie, Y. Lin, C. Li, D. Wu and H. Kong, Powder Technol., 2015, 269(4), 351-357.

35 P. Bénézeth, D. A. Palmer, L. M. Anovitz and J. Horita, Geochim. Cosmochim. Acta, 2007, 71(18), 4438-4455.

36 G. Stoica and J. Pérez-Ramírez, Geochim. Cosmochim. Acta, 2010, 74(24), 7048-7058.

37 D. D. Wagman, W. H. Evans, V. B. Parker, R. H. Schumm, I. Har-Low, S. M. Bailey, K. L. Churney and R. L. Nuttall, J. Phys. Chem. Ref. Data, 1989, 11(suppl. 2).

38 B. S. Hemingway, R. A. Robie and J. A. Kittrick, Geochim. Cosmochim. Acta, 1978, 42(10), 1533-1543.

39 K. Kawazuishi and J. M. Prausnitz, Ind. Eng. Chem. Res., 1987, 26(7), 1482-1485.

40 Q. Zhao, S. Wang, F. Qin and C. Chen, Ind. Eng. Chem. Res., 2011, 50(9), 5316-5325.

41 H. Katsumi, M. Nishikawa, F. Yamashita and M. Hashida, J. Ceram. Soc. Jpn., 2010, 98(1137), 444-449.

42 T. Oikawa, Y. Masui, T. Tanaka, Y. Chujo and M. Onaka, J. Organomet. Chem., 2007, 692(1-3), 554-561.

43 Z. Wu, Y. Shen, Y. Dong and J. Jiang, J. Alloys Compd., 2010, 467(1), 600-604.

44 S. Melis, M. Verduyn, G. Storti, M. Morbidelli and J. Bałdyga, AIChE J., 1999, 45(7), 1383-1393.

45 J. P. Hsu and B. T. Liu, J. Colloid Interface Sci., 1998, 198(1), 186-189. 
46 D. K. Owens and R. C. Wendt, J. Appl. Polym. Sci., 1969, 13(8), 1741-1747.

47 X. B. Li, L. Yan, D. F. Zhao, Q. S. Zhou, G. H. Liu, Z. H. Peng, S. S. Yang and T. G. Qi, Trans. Nonferrous Met. Soc. China, 2013, 23(5), 1472-1479.

48 B. M. Yu, Adv. Mech., 2003, 33(3), 333-340.

49 J. Ji, X. Z. Duan, G. Qian, X. G. Zhou, G. S. Tong and W. K. Yuan, Int. J. Hydrogen Energy, 2014, 39(24), 1249012498.

50 A. A. Taromi and S. Kaliaguine, Appl. Catal., A, 2018, 558, 140-149.

51 M. Thommes, K. Kaneko, A. V. Neimar k, J. P. Olivier, F. Rodriguez-Reinoso, J. Rouquerol and K. S. W. Sing, Pure Appl. Chem., 2016, 38(1), 25.
52 M. J. Readey, R. R. Lee, J. W. Halloran and A. H. Heuer, J. Am. Ceram. Soc., 2010, 73(6), 1499-1503.

53 S. M. Hassanizadeh and W. G. Gray, Water Resour. Res., 1993, 29(10), 3389-3405.

54 D. Y. Peng and D. B. Robinson, Minerva Ginecol., 1976, 12(11-12), 3069-3078.

55 J. W. Choi, S. Y. Lee, S. H. Lee, J. E. Kim, K. Y. Park, D. J. Kim and S. W. Hong, Water, Air, Soil Pollut., 2012, 223(6), 28812890.

56 S. Mor, K. Chhoden, P. Negi and K. Ravindra, Environmental Nanotechnology, Monitoring and Management, 2017, (7), 1523.

57 T. Liu, K. Wu and L. Zeng, J. Hazard. Mater., 2012, (217-218), 29-35. 